\title{
Energy audit and energy efficiency of modular military towns
}

\author{
Olga Gamayunova ${ }^{1,}{ }^{*}$, Anton Radaev ${ }^{1}$, and Mikhail Petrichenko ${ }^{1}$, and Natalia Shushunova ${ }^{2}$ \\ ${ }^{1}$ Peter the Great St. Petersburg Polytechnic University, Polytechnicheskaya, 29, St.Petersburg, \\ 195251, Russia \\ ${ }^{2}$ Moscow State University of Civil Engineering, 26, Yaroslavskoye Shosse, Moscow, 129337, Russia
}

\begin{abstract}
The Ministry of Defense of the Russian Federation continues to actively modernize military towns: the bet is placed on prefabricated modular buildings. Such buildings comply with the basic requirement for military installations - mobility. The article presents examples of existing modular military towns, as well as the results of a thermal survey of fencing structures of a modular building to accommodate military personnel.
\end{abstract}

\section{Introduction}

When designing military installations, the main requirements are mobility, low weight, the ability to instantly dismantle, roll up, transfer to another location, deployment and installation in a new location. For this, cheap pre-fabricated barracks and military towns based on a modular structure, built in Russia and abroad (see Fig. 1) are ideally suited.

Modular military towns are full-fledged residential buildings with all necessary life support components: electricity, water supply and heating. The modular technology of construction of objects in many ways exceeds capital construction:

1. Flexibility of choosing layouts. The block-modular architecture is universal and allows you to build dormitories, canteens, car washes and other facilities.

2. Minimum permits. A modular building is not an object of capital construction - the process of building approval is as simple as possible.

3. Possibility to erect buildings up to three floors. On the basis of block modules it is allowed to create multi-storey buildings, thereby rationally managing the land.

4. High reliability and durability of frames. The frame of the blocks has a significant margin of safety and durability and allows to erect buildings in difficult climatic conditions.

5. Ease and high speed of installation. The blocks are supplied with primary interior decoration, which speeds up the construction of the building, and convenient fasteners and thoughtful design make this process simple

6. Cheap delivery to the site. The use of collapsible modules instead of welded reduces the cost of delivery up to four times. However, this increases the time and cost of installation. It is important to keep a balance

\footnotetext{
*Corresponding author: gamayunova_os@spbstu.ru
} 
7. Simplified foundation requirements. The foundation for a mobile building can be quite simple. Of course, you can prepare and expensive monolithic base, but in most cases there is no need.

8. Potential possibility of dismantling. If necessary, a modular building can be relatively quickly disassembled, which is important when this building needs to be transported to another object.

However, it is also worth noting several drawbacks of modular buildings:

- low floors (usually not more than three floors);

- limiting the overall dimensions (in view of the fact that the production and installation of a modular building takes place in different places, you need to consider the possibility of transporting the blocks and, accordingly, their dimensions).

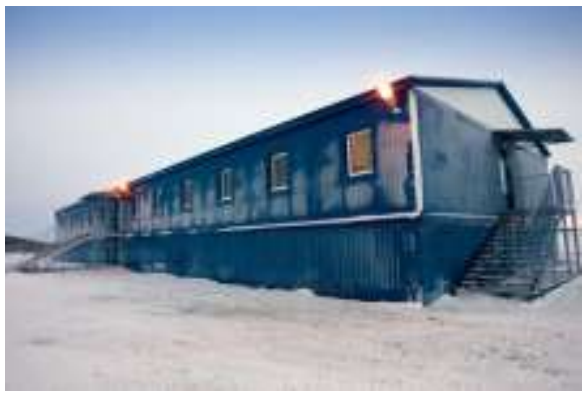

a)

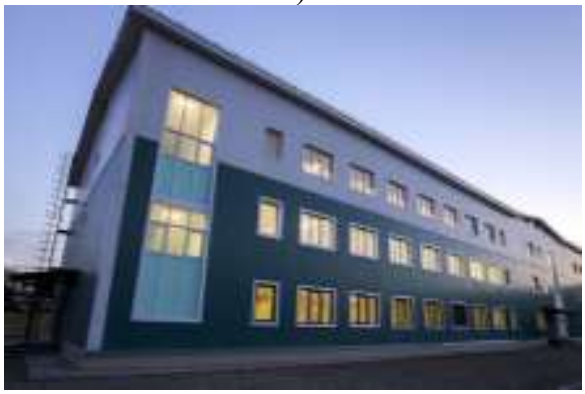

c)

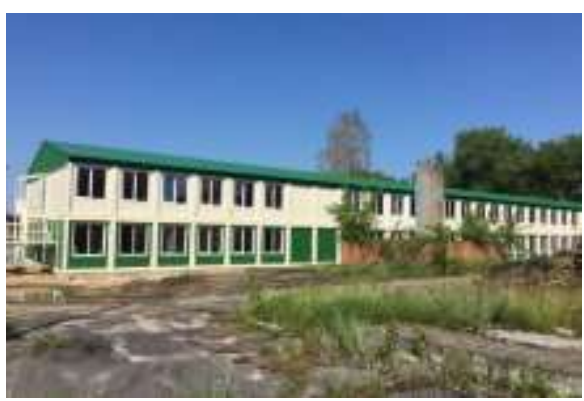

b)

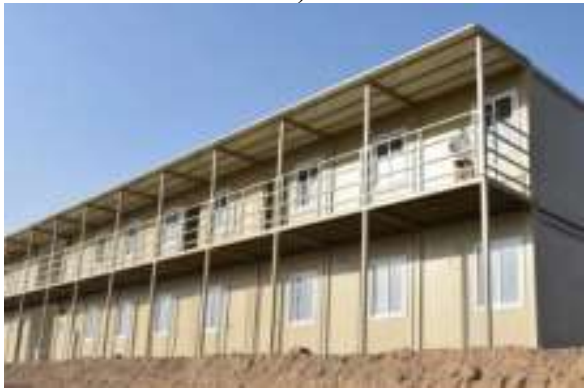

d)

Fig.1. Modular military towns: a) military town on Wrangel Island (Arctic), b) barracks on the basis of 160 modules (Russia, Bryansk region, Klintsy); c) modular barracks in the military town "Monastyrishche" (Russia, Primorsky Krai ); d) modular pre-fabricated barracks (China, Urumqi).

\section{Materials and Methods}

Modular buildings, as, in general, and any other buildings and structures, may suffer from hidden defects that are difficult to detect and, accordingly, to eliminate. As a rule, problems in buildings appear due to improper design, construction or maintenance.

According to Federal Law No. 261 dated 2009/11/23 “On Energy Saving and Improving Energy Efficiency and Amendments to Certain Legislative Acts of the Russian Federation", compliance with energy efficiency requirements must be ensured during the design, construction, reconstruction, and overhaul of the building, buildings, structures. This requirement also applies to modular buildings designed in recent years.

Let's consider on a concrete example how modular buildings meet the requirements for energy efficiency. Energy Efficiency and Energy Audit" (Moscow, Russia) presented the results of thermal imaging quality control of thermal protection of enclosing structures of a 
modular building to accommodate 200 servicemen (see Fig. 2). The building is located on the territory of the military camp number 6 at the address: Moscow Region, Naro-Fominsky District, pos. Kalininets.

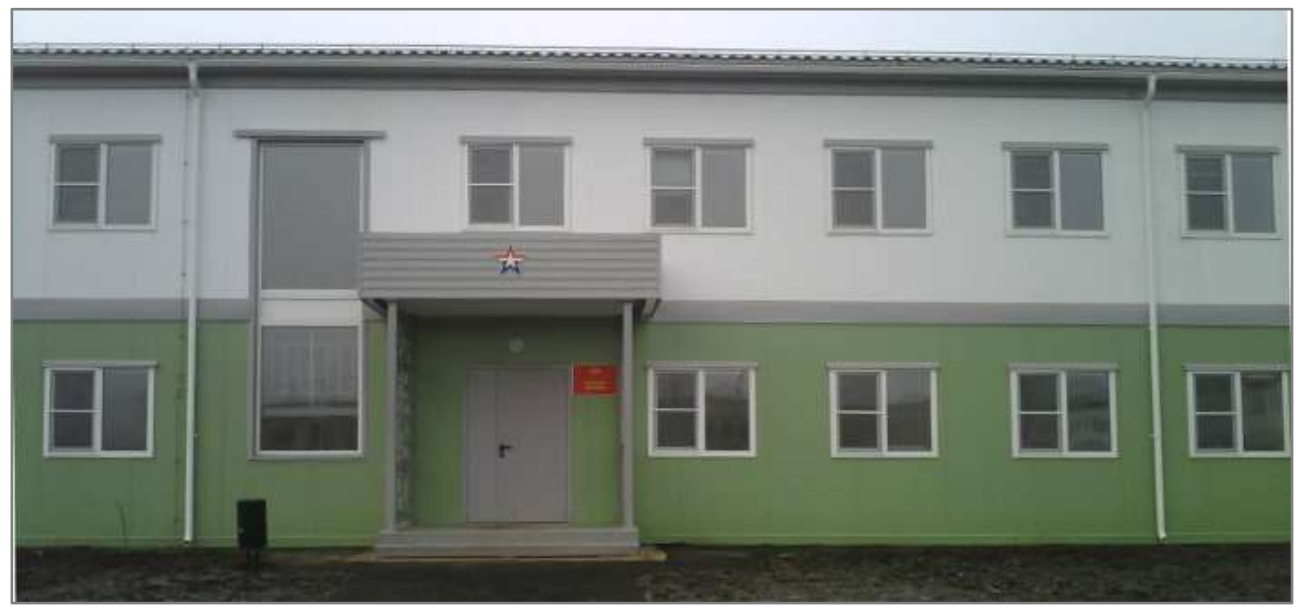

Fig.2. Modular building to accommodate military personnel

The report on the thermal imaging survey of a modular building included a description of the instruments and diagnosis equipment, a description of the research method, the results of the thermal imaging survey (including defect maps), a technical conclusion, etc. One of the defect maps is shown on Fig.3.

This defect map shows that there are no heat engineering anomalies and defective areas that reduce the thermal insulation characteristics of the enclosing structures on the facade of the building. Standard heat loss through translucent structures.

The final report on the thermal imaging survey of a modular building for military personnel includes the following conclusions:

1. At the time of the survey, there were no pronounced thermal anomalies on the facade of the building.

2. The thermal field of the facades is uniform with insignificant temperature variations along the plane due to uneven wind load.

3. Anomalous temperature zones that clearly reduce the thermal insulation characteristics of the enclosing structures were not found.

4. Identified areas of heat loss on the porch door leaf.

5. According to the thermograms obtained as a result of thermal imaging control of the outer and inner surfaces of the enclosing structures, it has been established:

- temperature difference between the temperatures of the internal air and temperature on the surface of the enclosing structures and temperature on the internal surface above the dew point temperature

- requirements of SNiP 23-02-2003, clause 5.1 are fulfilled, no defects were detected.

- the temperature fields on the surfaces and in the places of conjugation of the enclosing structures are homogeneous, no anomalous zones with elevated temperatures have been identified. 


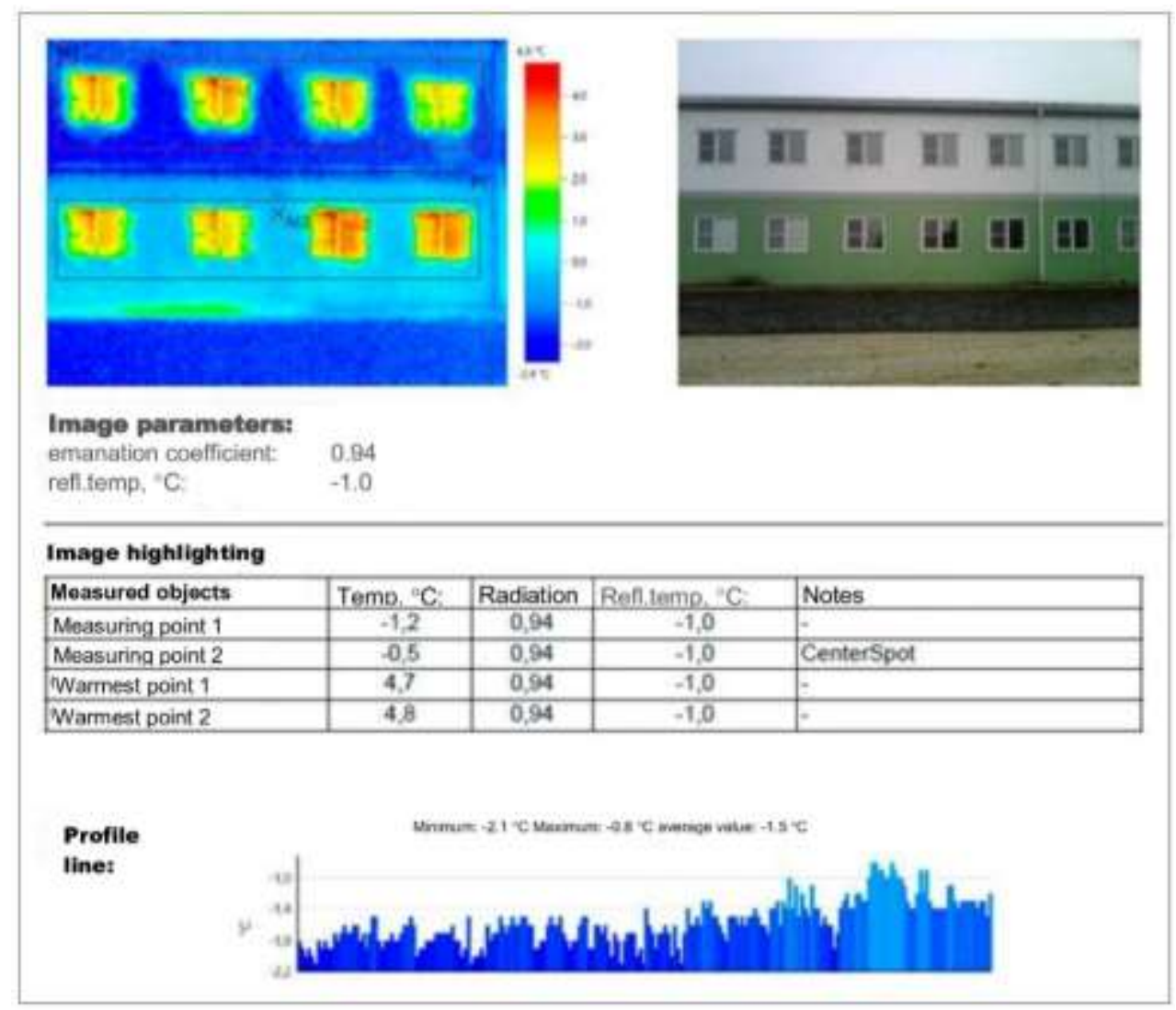

Fig.3. Defect map

\section{Conclusions}

When used properly, thermovision inspection helps to find and fix most of the hidden problems and defects in buildings, structures and equipment. If left unattended, they can lead to the destruction of expensive equipment, buildings, building structures, high maintenance and repair costs.

Thermovision inspection of a modular building showed that no significant thermal anomalies were detected on the facade of the building. This means that modern model modular buildings comply with energy efficiency standards and can continue to be massively used in the construction and modernization of military towns.

Prefabricated modular buildings (as compared to reinforced concrete and brick) make it possible to obtain a high-quality mobile facility in a short time and at an affordable price, which is very difficult in capital construction.

\section{References}

1. https://sms-m.ru/modulnie-zdaniya (last accessed 13.12.2018)

2. https://energo-audit.com/teplovizionnoe-obsledovanie (last accessed 16.12.2018) 
3. https://energo-audit.com/teplovizionnoe-obsledovanie-modulnogo-zdania (last accessed 16.12.2018)

4. N. A. Skorikova, History of planning and development of the military town number 19 in Irkutsk. In: News of the laboratory of ancient technologies, 1(22), 132-147 (2017)

5. M. R. Petrichenko, E. V. Kotov, D. V. Nemova, D. S. Tarasova, V. V. Sergeev, Magazine of Civil Engineering, 1(77), 130-140 (2018)

6. D. D. Zaborova, M. I. Kukolev, M. T. Mussorina, M. R. Petritchenko, The simplest mathematical model of the energy efficiency of layered building envelopes. In: St. Petersburg polytechnic university journal of engineering science and technology, 4(254), 28-33 (2016)

7. T. A. Musorina, O. S. Gamayunova, M. R. Petrichenko, Thermal regime of enclosing structures in high-rise buildings, 8(119), 935-943 (Vestnik MGSU, 2018)

8. T. A. Musorina, O. S. Gamayunova, M. R. Petrichenko, Substantiation of design measures to increase energy efficiency of exterior walls, 11(110), 1269-1277 (Vestnik MGSU, 2017)

9. A. S. Gorshkov, N. I. Vatin, P. P. Rymkevich, O. O. Kydrevich, Payback period of investments in energy saving, Magazine of Civil Engineering, 2(78), 65-75 (2018)

10. E. A. Statsenko, A. F. Ostrovaia, T. A. Musorina, M. I. Kukolev, M. R. Petritchenko, The elementary mathematical model of sustainable enclosing structure. In: Magazine of Civil Engineering, 8(68), 86-91 (2016)

11. N. I. Vatin, A. Y. Ivanov, Y. L. Rutman, S. A. Chernogorskiy, Earthquake engineering optimization of structures by economic criterion. In: Magazine of Civil Engineering, 8(76), 67-83 (2017)

12. E. A. Martynenko, A. A. Staritcyna, V. A. Rybakov, Reconstruction of the Residential District of St. Petersburg Historic Center, Construction of Unique Buildings and Structures, 1(40), 32-42 (2016)

13. E. Gumerova, O. Gamayunova, T. Meshcheryakova, Energy efficiency upgrading of enclosing structures of mass housing of the soviet union, In: Advances in Intelligent Systems and Computing, 692, 432-439 (2018)

14. A. E. Radaev, V. V. Kobzev, Optimizing the configuration for the supply network of industrial enterprises based on the probabilistic process model, 6(256), 166-178 (St. Petersburg State Polytechnical University Journal. Economics, 2016)

15. O. Gamayunova, E. Gumerova, N. Miloradova, E3S Web of Conferences, 90, 02046 (2018)

16. O. Gamayunova, M. Petrichenko, T. Musorina, E. I. Gumerova, Feasibility study of the insulation of the enclosing walls of high-rise buildings. In: International Scientific Conference on Energy, Environmental and Construction Engineering (EECE-2018) electronic edition. Serie. "MATEC Web of Conferences", 06006 (2018)

17. O. S. Gamayunova, E. I. Gumerova, Energy-saving glazing as a method for increasing the energy efficiency of high-rise buildings. In: SPbPU Science Week. Materials of a scientific conference with international participation. Civil Engineering Institute, 339$341(2018)$ 